ISSN: 2224-0616

Int. J . Agril. Res. Innov. \& Tech. 5(2): 51-57, December, 2015 Available online at http://www.ijarit.webs.com

\title{
TEMPORAL VARIATION IN SEED QUALITY OF INDIAN SPINACH PRESERVED IN DIFFERENT CONTAINERS
}

\author{
M. Kamruzzaman', S. Khatun', A. Rakib², M.I. Hoque' ${ }^{2}$ and M.H. Rani1 \\ Received 5 October 2015, Revised 27 November 2015, Accepted 22 December 2015, Published online 31 December 2015
}

\begin{abstract}
The experiment was conducted to investigate the seed quality of Indian spinach for three months stored at different containers (Plastic pot, polythene bag and cloth bag) during 2013-2014 at Seed Technology Laboratory of Bangabandhu Sheikh Mujibur Rahman Agricultural University (BSMRAU), Gazipur. The initial moisture content of the seed was $9.89 \%$ with $75.00 \%$ germination. However, after two months, the seed had a different range of increased moisture content with reduced germination percentage depending upon the packing materials. Among the three containers, seeds stored at cloth bag absorbed more moisture (14.36\%) from surrounding atmosphere followed by the moisture content, $12.67 \%$ and $11.50 \%$ of polythene bag and airtight plastic pot, respectively. Seeds stored at plastic pot, polythene bag and cloth bag exhibited 65.00, 64.00 and 50.00 per cent germination, respectively. Similarly, the fresh weight and dry weight of seedling and seedling vigor were also decreased. The seeds of plastic pot were good in term of germination capacity, fresh and dry weight and vigor index in comparison to those stored at cloth bag and polythene bag.
\end{abstract}

Keywords: Germination Percentage, Moisture Content, Fresh and Dry weight

\footnotetext{
${ }^{1}$ Plant Breeding Division, Bangladesh Institute of Nuclear Agriculture, BAU Campus, Mymensingh-2202, Bangladesh

${ }^{2}$ Scientific Officer, Bangladesh Institute of Nuclear Agriculture BINA Sub- station, Ishurdi, Pabna, Bangladesh

*Corresponding author's email: soyemabina14@yahoo.com (S. Khatun)
}

\section{Introduction}

Indian spinach is a very popular leafy vegetable of Bangladesh, and available in few other countries of Asia and Africa. The nutritive value of Indian spinach is very high with a good content of minerals and a moderate storage of vitamins for the human diet plus substantial amount of fiber and that of water. The plant is reported to contain the following salts and vitamins: Water (93\%), Protein (1.2\%), Iron (1.4\%), Calcium (0.15\%), and Vitamin-A (3250 $\mathrm{IU} / 100 \mathrm{~g})$. In addition, it contains $16 \mathrm{~g}$ fluoride/ $100 \mathrm{~g}$ and nitrate content is $764 \mathrm{ppm}$ on dry weight basis (Sanni, 1983). Good seed is a basic input in vegetable production. Successful olericulture program depends on the quality of seeds used for sowing. Thus, the seed producers hold greater responsibility in maintaining genetically pure seeds and to preserve the quality of seeds from harvest to next sowing. Deterioration of seed is associated with ageing phenomenon, which is defined as an irreversible degradation change in the quality of a seed after it has reached stage. Its maximum quality level and the seed deterioration also start immediately after attaining the physiological maturity on the plant itself (Abdul-Baki and Anderson, 1973). Seed storage and retention of seed viability are always an important consideration in agricultural practices. As the seed is hygroscopic in nature, its quality is being affected due to variations in the environmental conditions viz., relative humidity, temperature, moisture content, gaseous exchange, packaging material etc. (Doijode, 1988). Poor storage condition gives rise to deterioration of seed quality and the resultant loss of viability. Poor storage conditions greatly affect seed vigor (Heydecker, 1979). Vigor of seed at the time of storage is important factors that affect storage life. To combat these factors effectively storing the seeds in vapor proof containers like polythene bag, aluminium foils, tins or any sealed containers is found to be more useful in maintaining the desired quality of seeds for longer period (Singh and Singh, 1992), unlike those stored in moisture pervious containers like cloth bag and gunny bag (Singh et al., 1988). Attempts have been made by several workers in many crops to develop methods for maintaining the viability and vigor of seeds for longer period during storage. It is well known fact that the choice of materials for seed treatment, containers selected for storing the seeds and storage environment exert a positive effect on the viability and vigor of seeds in storage. The information on prolonging the shelf life of Indian spinach seeds under storage is very limited and hence the present study has been undertaken with following objectives: 
i. To evaluate the germination percentage of seeds, viability and vigor of seedlings of Indian spinach contained in different containers;

ii. To know the effect of moisture on the germination percentage of Indian spinach seed.

\section{Materials and Methods}

After recording the initial moisture content and germination percentage, seeds were kept in three containers: plastic pot, polythene bag and cloth bag (Fig. 1) and stored at room temperature $\left(25^{\circ}\right.$ C) and RH for two months. Germination test and recoding the moisture content (wet basis) was performed every 20 days interval beginning from collection of seeds up to 60 days to observe the rate of natural ageing in different containers.

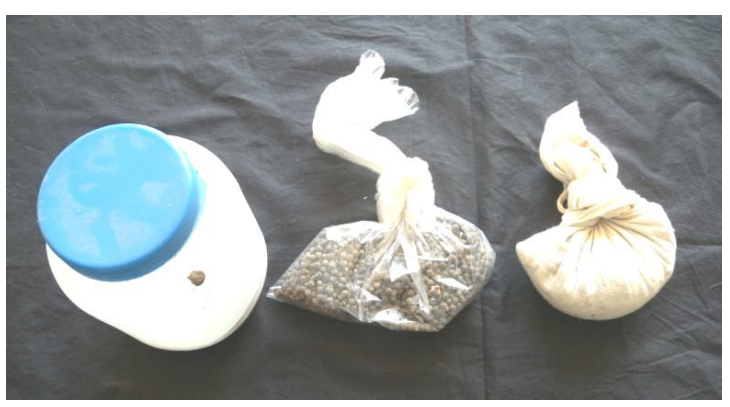

Fig.1. Containers used for storage of seeds

\section{Moisture content}

Moisture content was determined by using high constant temperature oven method following International Rules for Seed Testing (ISTA, 2015) in the Agronomy Laboratory of BSMRAU. Seeds of $5.0 \mathrm{~g}$ were taken from each three containers, poured in a small container with cover, and kept in an oven maintained at a temperature of $130^{\circ} \mathrm{C}$ for a period of 1 hour. The moisture content of seeds (wet basis) was determined by the following formula (ISTA, 2015).

$$
\operatorname{MC}(\%)=\frac{M_{2}-M_{3}}{M_{2}-M_{1}} \times 100
$$

$$
\begin{aligned}
\mathrm{M}_{1}= & \text { Weight of container }+ \text { cover } \\
\mathrm{M}_{2}= & \text { Weight of container }+ \text { cover }+ \text { Mustard seed } \\
& \text { before drying } \\
\mathrm{M}_{3}= & \text { Weight of container }+ \text { cover }+ \text { Mustard seed } \\
& \text { after drying }
\end{aligned}
$$

\section{Germination test}

Germination test was conducted by following sand method. For germination, test seeds were soaked in water for overnight and placed in plastic tray with moist sand. 400 seeds were taken randomly from the seed samples of each container. 100 seeds were placed on a plastic tray with 4 replications. The plastic trays with seed were incubated at room temperature. After 4 days of incubation first count were done and after 14 days final count was recorded following ISTA rules. Germination percentage was calculated using the following formula (Krishnasamy and Seshu, 1990).

Germination (\%)

$$
=\frac{\text { Number of seeds germinated }}{\text { Number of seeds tested }} \times 100
$$

\section{Seedling vigor}

Seed vigor is the sum total of all those properties in seed which, upon planting, result in rapid and uniform production of healthy seedlings under a wide range of environments including both favorable and stress conditions (Association of Official Seed Analysts, USA). However, the technique of vigor index includes following formula given by Maguire (1962).

$$
\begin{aligned}
& \text { VI }=\frac{\text { Number of zeeds germinated (iat count) }}{\text { Days to firat count }} \\
& +\ldots .+\frac{\text { Number of geed geminated (last count) }}{\text { Days to final count }}
\end{aligned}
$$

\section{Seedling evaluation}

Seedlings obtained from standard germination test were used for seedling evaluation. Normal or abnormal seedlings were classified according to the rules of ISTA (2015). Seedling shoot and root length was measured on day 14 of the germination test. Ten plant samples from each plastic pot were harvested and shoot and root length of individual plant was recorded and their wet weight and dry weight were measured. After taking fresh weight, samples were kept in a drying oven for 72 hours at $70^{\circ} \mathrm{C}$ temperature.

\section{Insects and diseases}

For observation of biotic factor that influence seed quality, $20 \mathrm{~g}$ of Indian spinach seeds were taken and observed the numbers and kind of insects or pathogen were present.

No biotic factors like insects and pathogen was observed during the storage period in all the containers. It might be due to the storage period was short (around 2 months) and the storage climate was not favorable for insects and pathogen activity for Indian spinach seeds.

\section{Recording of weather data}

Reading of dry bulb and weight bulb temperature and relative humidity of inside the room and outside the room was recorded in 9.00 AM and 5.00 PM a day. Maximum and minimum temperatures were recorded from outreach room conditions of BSMRAU. 


\section{Results and Discussion}

\section{Moisture content of seed}

During storage period moisture of Indian spinach seeds of three containers was determined and recorded (Table 1). Seed moisture content is the most important factor that regulates the longevity of the seeds. Higher moisture in seeds enhances seed deterioration, which ultimately reduces the planting value of seeds in the field. Initial moisture content of seeds of before storage was $9.89 \%$ (Table 1). The seed of cloth bag came to the contact with air and their moisture contents was increased sharply from initial moisture content 9.89 to $14.36 \%$ but the increasing moisture contents rate of seeds of airtight plastic pot and poly bag is slow. As seed is highly hygroscopic living material, it absorbs moisture from air if it is stored in an environment where relative humidity is higher than seed moisture content (Copeland, 1976). The relative humidity was near $75 \%$ or above through the storage period (Fig. 2). For this reason, seed absorbed moisture from the ambient air and tended to equilibrium with relative humidity. The rate of absorbance was higher in cloth bag because of cloth bag was not air tight container but plastic pot and polythene bag were moisture proof so, increasing rate was lower in air tight container.

Table 1. Moisture content (\%) of Indian Spinach seeds stored in different containers with different storage period

\begin{tabular}{lccccc}
\hline Containers & $\begin{array}{c}\text { Initial moisture } \\
\text { content (\%) }\end{array}$ & $\begin{array}{c}\text { Moisture (\%) } \\
\text { after 15 days }\end{array}$ & $\begin{array}{c}\text { Moisture (\%) } \\
\text { after 30 days }\end{array}$ & $\begin{array}{c}\text { Moisture(\%) } \\
\text { after 45 days }\end{array}$ & $\begin{array}{c}\text { Moisture (\%) } \\
\text { after 60 days }\end{array}$ \\
\hline Plastic pot & 9.89 & 10.14 & 10.50 & 11.00 & 11.50 \\
Polythene bag & 9.89 & 10.44 & 11.65 & 12.10 & 12.67 \\
Cloth bag & 9.89 & 12.65 & 13.24 & 13.95 & 14.36 \\
\hline
\end{tabular}

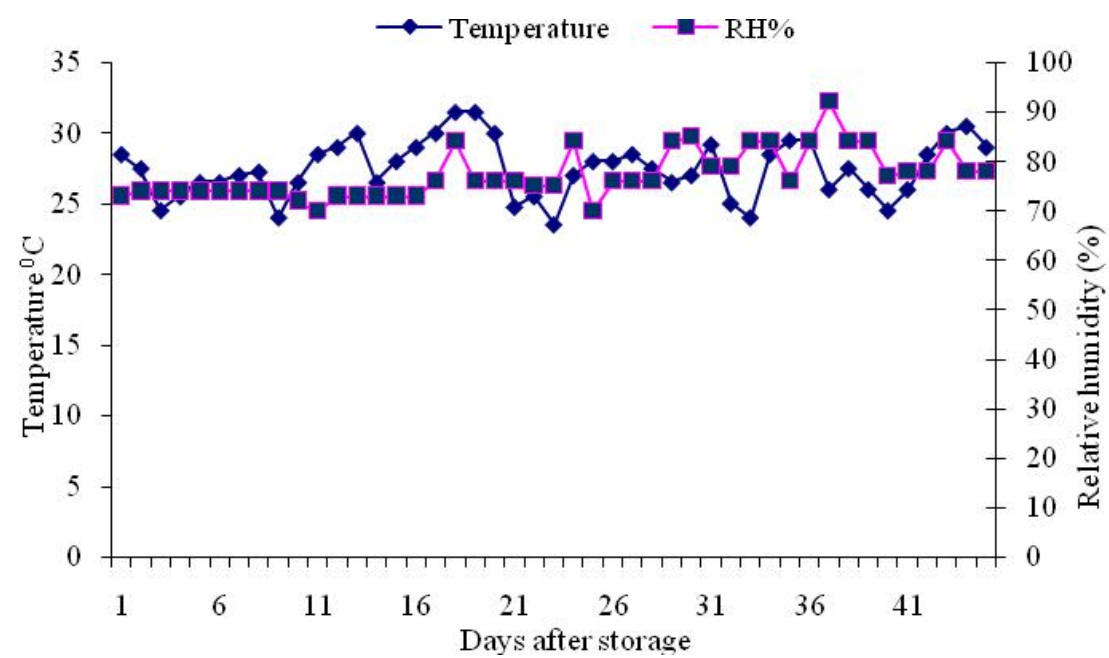

Fig. 2. Mean temperature and relative humidity during storage period (1 April 2013 to 29 May 2013)

\section{Germination}

Seed germination test provides to the ability of seeds to germinate and produce a seedling that will emerge from the soil and develop onto a healthy vigorous plant. The initial germination percentage of all containers' seeds was around (75\%) but after storage, it was declined (Fig. 3 and Fig. 4). The decline rate of germination percentage was higher in seeds of cloth bag by $27 \%$ followed by 8 and $7 \%$ in polythene bag and plastic bag, respectively. Seed deterioration is natural phenomena and life span of seeds decrease with the passing of time and increasing abnormal seedling and dead seeds, the increasing rate of abnormal seedling and dead seeds were higher (12.30\%) in seeds of cloth bag compare to seeds of other containers (Fig. 5 and Fig. 6). Seed deterioration processes however, depend on a large number of genetical and environmental factors. Seed viability and vigor highly depends on the type of storage container. Closed metal containers like tin, airtight plastic pot, can and polyethylene bag were found to be better for storing seed at farmer level (Ali, 1963). As seed is highly hygroscopic living materials and it absorbs moisture from the surrounding atmosphere. This higher moisture in the seed may be the main reason of quick quality deterioration in the seeds of cloth bag. 


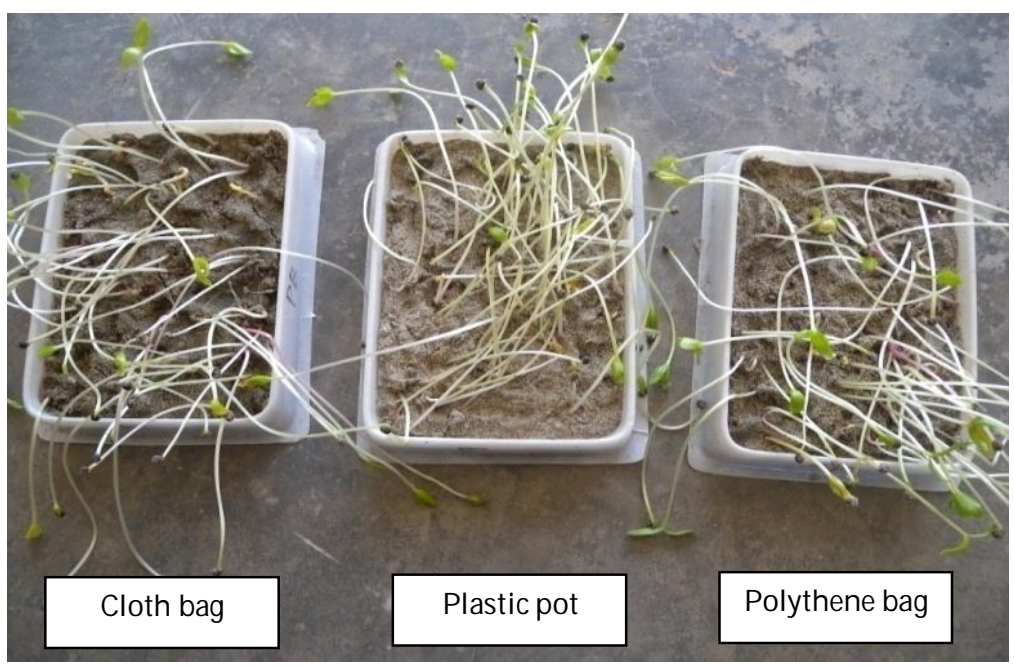

Fig. 3. Germination test of Indian spinach seeds stored in different containers

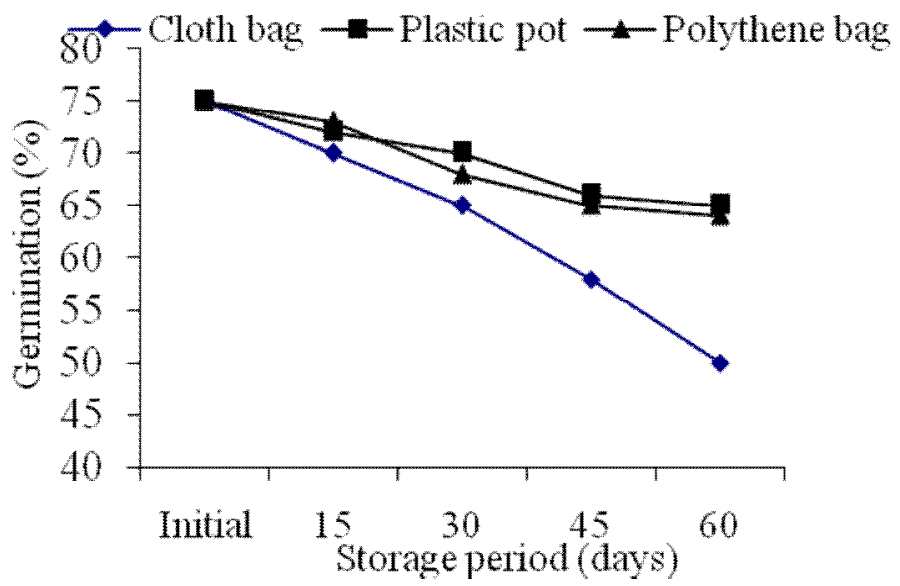

Fig. 4. Germination percentage of Indian spinach seeds stored in different types of containers

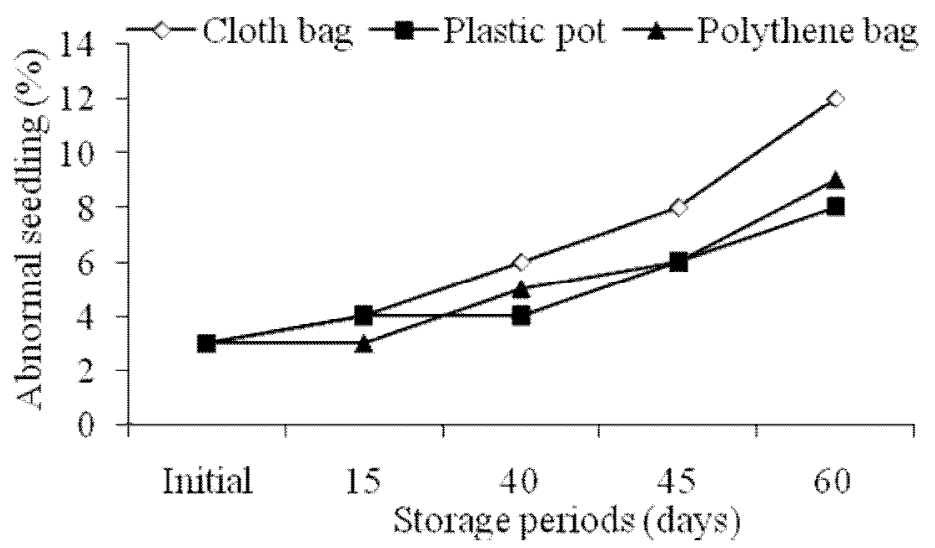

Fig. 5. Effect of storage container on abnormal seedling of Indian spinach seed stored at different period 


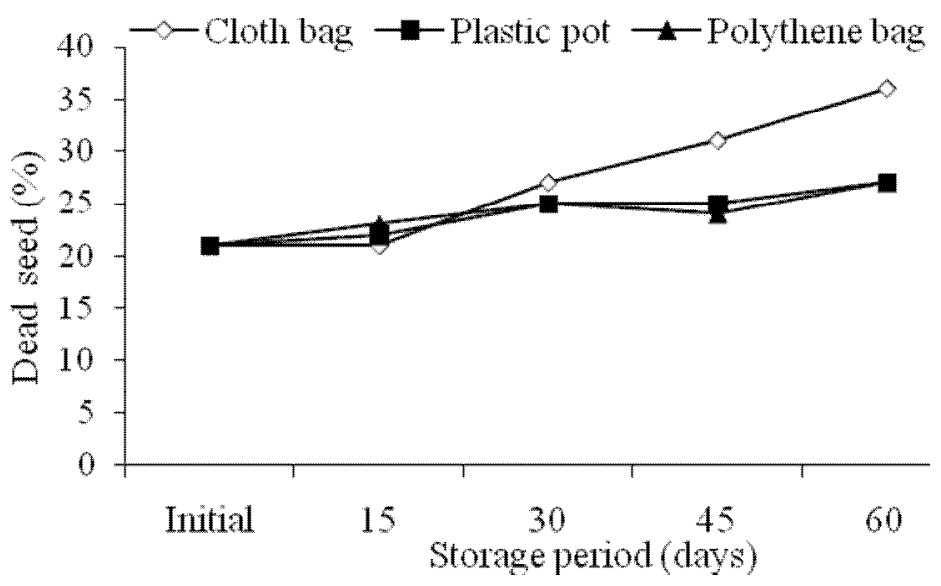

Fig. 6. Effect of storage container on dead seed of Indian spinach seed stored at different period

\section{Vigor index}

Seed germination test provides an indication about seedling vigor as well as performance of seed in the field. It was observed that Vigor index was better in seeds of plastic pot and polythene bag compared to that of cloth bag (Fig. 7). It may be due to the high relative humidity prevailed during the storage period. The seeds of non-air tight container (cloth bag) absorbed moisture from the surrounding atmosphere as a result respiratory activity and other physiological activities increased on the other hand stored food also decreased. Better germination indicates of air tight containers were the resultant of absence of dead seeds as well as lower number of abnormal seedlings (Fig. 5 and Fig. 6). Higher seed moisture contributed to maximum seed deterioration as higher is the seed moisture content lower is the seed longevity (Khandakar, 1983).

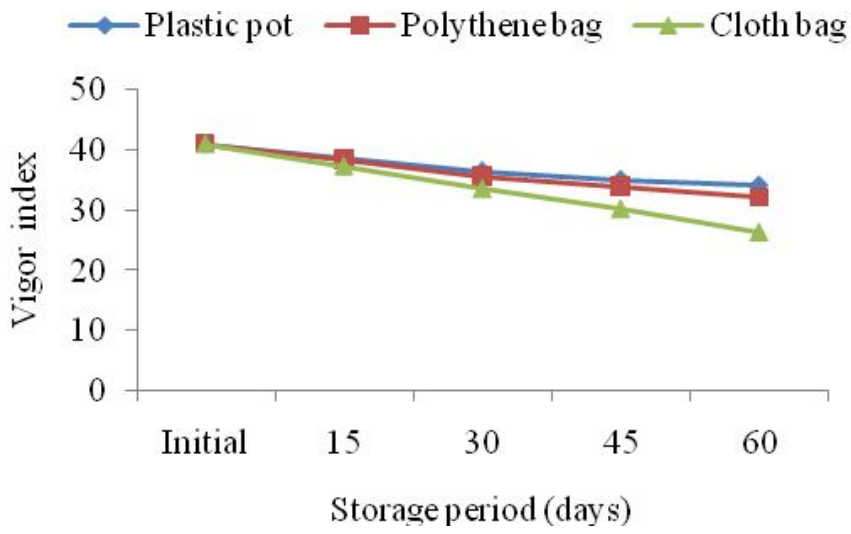

Fig .7. Vigor index (Germination rate) of Indian spinach seeds stored in different containers

\section{Seedling growth}

Seed quality of Indian spinach was evaluated by following seedling characters: (i) root- shoot length (ii) seedling fresh and dry weight. Seedling characters like shoot length, root length varied over storage containers and storage period (Fig. 8). The initial shoot length was $14.3 \mathrm{~cm}$ and root length was $8.0 \mathrm{~cm}$. The root fresh weight and dry weight were initially $88 \mathrm{mg}$ and $15 \mathrm{mg}$ and shoot fresh weight and dry weight were initially 43.4 mg and $20.0 \mathrm{mg}$ (Fig. 6), respectively. Both the lengths and weights were decreased with increasing storage period. The decreasing rate is higher in cloth bag compare to other containers. It might be due to faster rate of moisture increase and high respiratory activity resultant to shorten the storage food materials. 

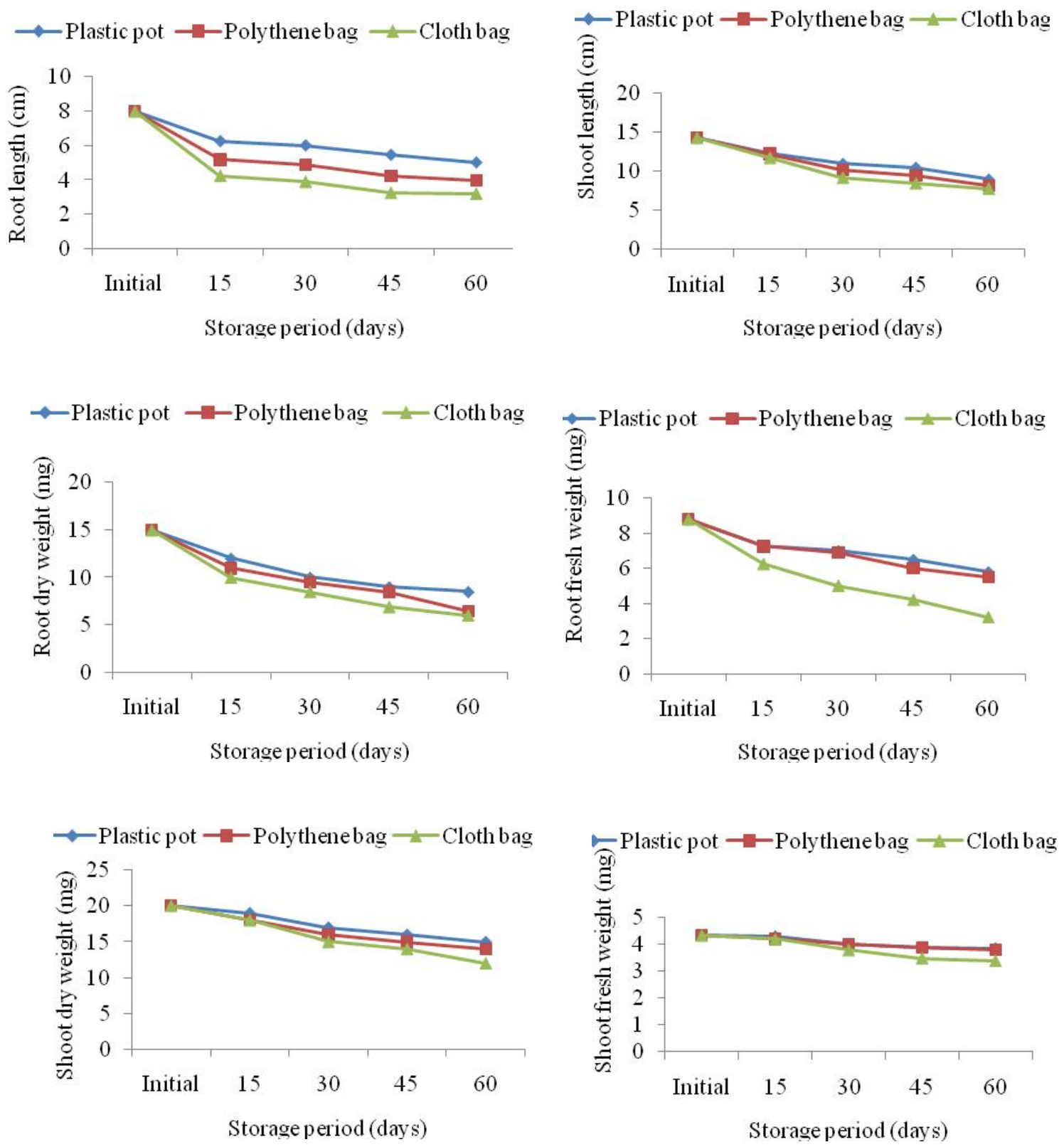

Fig. 8. Root and shoot length and fresh weight and dry weight of seedlings stored in different containers.

\section{Conclusion}

The present study revealed that the best container for the Indian spinach's seed preservation was plastic pot. The seed stored in plastic pot absorbed low moisture from atmosphere and showed low seed dead and abnormal seedling rate. On the other hand, seed stored in plastic pot gave the maximum germination percentage, high seedling vigor and best seedling growth. So, the plastic pot might be recommended for the preservation of Indian spinach's seed.

\section{References}

Abdul-Baki, A.A. and Anderson J.D. 1973. Physiological and biochemical deterioration of seed. In: Seed Biology (II Ed): Kozlowski, T.T., Academic Press, New York, London. pp 283-315.

Ali, M.K. 1963. Effect of storage containers on the moisture content, viability and other qualities of jute seed. Pak. J. Sci. Res. 15: 35. 
Copeland, L.O. 1976. Principles of Seed Science and Technology. Burgess Pub. Com., Minnaeapolis, Minnesofa. pp 164-165.

Doijode, S.D. 1988. Effect of storage environment on brinjal (Sorghum melongena) seed viability. Prog. Hort. 20: 292-293.

Heydecker, W. 1979. The vigor of seeds- a review. In: Proc. Int. Seed Test Association, vol 34, pp. 201-209.

ISTA. 2015. International Rules for Seed Testing. International Seed Testing Association. DOI: 10.15258/istarules.2015.i

Khandakar, A.L. 1983. Physio-chemical examination of jute seed (Corchourus capsularies) and (C. olitorius) for quality. Bangladesh J. J ute Fib. Res. 8: 1-4.

Krishnasamy, V. and Seshu, D.V. 1990. Germination after acclerated aging and associated characters in rice varieties. Seed Sci. Tech. 18: 353-359.

Maguire, J.D. 1962. Speed of germination - aid in selection and calculation of seedling emergence and vigour. Crop Sci. 2: 176-177.

Sanni, S.B. 1983. Vegetable cultivation. J. Sci. Food \&Agric. 32: 686-687.

Singh, G. and Singh, H. 1992. Maintenance of germinability of soybean (Glycine max L.) seeds. Seed Res. 20: 49-50.

Singh, S.N., Srivastava S.K. and Agrawal S.C. 1988. Viability and germination of soybean seeds in relation to pre-treatment with fungicides, period of storage and type of storage conditions. Trop. Agric. 65(2): 106108. 